\title{
Knowledge Levels of Farm Women on Value Addition of Vegetable in Ranga Reddy District
}

\author{
R. Neela Rani ${ }^{1}$, B. Jamuna Rani ${ }^{2}$, Y. Uma Jyothi ${ }^{1 *}$, T. Kamalaja ${ }^{3}$, \\ K. Swetha ${ }^{1}$, J. Deepika ${ }^{1}$ and K. Rajeswari ${ }^{1}$
}

${ }^{1}$ All India Coordinated Project on Women in Agriculture -Extension, ${ }^{2}$ Extension Education Institute, ${ }^{3}$ All India Coordinated Project on Women in Agriculture-Foods and Nutrition, Professor Jayashankar State Agricultural University, Hyderabad, India

*Corresponding author

\begin{tabular}{l} 
K e y w o r d s \\
$\begin{array}{l}\text { Awareness, } \\
\text { Value Addition, } \\
\text { Market analysis, } \\
\text { Vegetable growers }\end{array}$ \\
\hline Article Info \\
\hline $\begin{array}{l}\text { Accepted: } \\
\text { 26 September } 2020 \\
\text { Available Online: } \\
\text { 10 October } 2020\end{array}$ \\
\hline
\end{tabular}

\section{A B S T R A C T}

In Indian Economy agriculture plays a vital role. More than 75 percent of the people of our country tie up with agriculture directly and indirectly. India being an agricultural country, vegetables play a major role in food security and income for the poor farmers thus improving the nation's economy. India is now the second largest producer of vegetables, contributing about 12.3 per cent to the world vegetable production. Vegetables are grown on an area of 6.25 million hectares in India and the important ones are brinjal, tomato, onion, okra/bhendi, cauliflower, cabbage, potato and green peas. The production of nutritious vegetables for the health of the people is the need of hour. Agri- systems are undergoing quick alterations and the occurrence of combined food supply chains is one of the most developing market phenomena of India. Value chain approach enables each chain member to implement specific production practices, share information and solve problems at each stage of the production process. The study explored the awareness levels of the vegetable farmer women from five adopted villages of All India Coordinated Project on Women in Agriculture (AICRP - HSc) through well-structured interview schedule for 100 respondents. Findings of the study revealed that among total 510 number of respondents from the adopted villages only 175 were growing vegetables. It was evident that Horticultural Officer (71.00\%) and Agricultural Officer (49.00\%) were the most contacted extension personnel once in a month followed by weekly contact of Agri university scientist $(48.00 \%)$.Majority percent 65 of respondents testified that they are placed at distance of above $10 \mathrm{Kms}$ while only 13 percent of respondents reported to be situated at less than $5 \mathrm{~km}$ to the markets. Most of 27 percent of respondents reported to sell to middle men followed by weekly bazar (20\%).In regard to level of knowledge about value addition of vegetables, majority of the respondents 84 per cent possessed low level while only 11 per cent medium level of knowledge about value addition of vegetable produce. In case of cleaning, grading, packing \& packaging, only 6 per cent of respondents had high, 12 per cent had medium and majority 82 percent of respondents found to have low level of knowledge. 


\section{Introduction}

India being an agricultural country, vegetables play a major role in food security and income for the poor farmers thus improving the nation 's economy. India is now the second largest producer of vegetables, contributing about 12.3 per cent to the world vegetable production. It is becoming a gradually important activity in the agricultural sector of the country following the development of irrigation and increased emphases given by the government to small scale commercial farmers. Recently, due to their high nutritional value vegetable do have ever rising demand both in local and foreign markets, In Telangana vegetable cultivation is under 1.718 hectares' area and production is 31.953 lakh MT (Horticulture of Telangana 2107) standing 11th in production of vegetable cultivation. Major vegetable types produced are Tomato, Brinjal, Cabbage, Cauliflower, Cucumber, Carrot \& Radish.

Value Chain can be defined as the full range of activities which are required to bring a product or service from conception, through the different phases of production (Kaplinsky, $\mathrm{R}$ and M. Morris 2001). Agribusiness is the 'sum total of all procedures involved in the production and supply of farm goods, production operation on the farm,storage, processing, and distribution of farm commodities and items made from them' (Davis and Goldberg, 1957).Value chains are important to let dealings to react to the market through linking production, processing and marketing activities to market needs. It also enables an enriched understanding of competitive challenges, helps in the identification of relationships and coordination mechanisms, and assists in understanding how chain actors deal with the chain. The promotion of value chains in agribusiness aims to improve the competitiveness of agriculture in national and international markets and to generate greater value to the product within the country.

Process of changing or transforming a product from its original state to a more valuable state is value addition. It is described as any activity carried out by the business that increases the value of its product or service and when a consumer is willing to pay more for additional output. It can be added at postharvest levels including process like grading, sorting, cutting, seeding, shelling packing etc. Value added forms of vegetables may be eaten equally or may be consumed in without affecting its nutrition and palatability. By value addition to the original produce it is also estimated that the extent of losses can be brought down to less than 50 per cent of the existing level on proper transfer and adoption of agro processing technology.

The net margin for the vegetable farmers is high only when their produce is value added and sold to individual consumers through unions or consumer cooperatives to reduce the number of middlemen across the market chain. Therefore, there is a strong need to make value chain analysis to identify the major vegetable value chain actors and their roles. Capacity building trainings to the vegetable farmers on value addition in the direction of increasing their purchasing value of the produce. An attempt has been made to explore awareness on market analysis and awareness on value addition of vegetable being followed by the vegetable growers of Maheswaram Mandal.

Prem Singh Arya (2002) concluded that vegetable research in India remained almost neglected in the first half of the century and still there is a wide gap between production and availability of vegetables in our country.

Krishnaiah (1997) suggested that there is need to concentrate on selected fruits, vegetables 
and spices where these crops enjoy comparative advantage in terms of production and exports.

Agro Economic Research Centre, University of Delhi (2006) brought to light that vegetable cultivation is advantageous in India than any other crop.

Sirohi and Moushumi Sarkar (2001) viewed that the proper pre-harvest management of vegetables is very important to reduce or minimize the amount of post-harvest losses which can save a lot of economic yield of vegetables.

Manojkumar (2006) observed that major problems in marketing of vegetables faced by the vegetable growers are related to inadequate inputs supply, lack of storage facilities, paucity of approach roads and absence of co-operative marketing societies for the marketing of vegetable crops.

Bezabih (2010), major market constraints include lack of markets facilities, low price for products, large number of middlemen in the marketing system, lack of marketing institutions safeguarding farmers' interest and rights over their marketable produces, poor product handling and packaging, imperfect pricing system, and lack of transparency in market information system mainly in the export market.

Anjani Kumar et al., (2011) found that only an insignificant proportion of horticultural produce $(2-3 \%)$ is processed, and the postharvest losses across horticultural commodities are alarming (25-30\%). The sector is constrained by low productivity, large post-harvest losses due to inadequate storage, cool chain and transport infrastructure, and inefficient supply chain management.

Kumari et al., (2020) revealed that farmers were not properly aware about the package of practices of cultivation of cauliflower and under or over utilizing the resources of productivity caused gap in output of the crop. Proper farmer's field trials and awareness campaigns on improved practices and correct method of use of inputs need to be imparted which will ultimately benefit the producers (Sonia Rani and Shehrawat, 2018).

Quality of those vegetables has to be improved by different value addition activities like upgrading, packaging, Processing, handling, grading and transportation system.

\section{Materials and Methods}

Maheswaram Mandal of Ranga Reddy district is a noticeable vegetable growing Mandal amongst Ranga Reddy district. It was selected purposively for the present investigation. The research was carried in 5 adopted villages of AICRP -WIA (AICRP Home Science) from Maheshwaram Mandal namely Pendyal, Ramachandraguda, Kalwakole, Dubbacherla and Lillipur villages where vegetables are grown. A total number of 100 samples were selected purposively from the adopted village of Maheswaram Mandal. Data was collected by interviewing the farm women personally through a detailed interview schedule. The responses were scored, quantified, categorized and tabulated using descriptive statistics for analyzing the data.

\section{Results and Discussion}

Table 1 indicates that among total 510 number of farmers from the adopted villages 175 were growing vegetables out of which 100 are taken for the sample purposively. This may be due to the availability of water and irrigation sources as vegetable cultivation requires continuous watering at different stages of crops.

Table 2, the frequency of contact with different extension personnel by farm women 
was given. It was evident that Horticultural Officer $(71.00 \%)$ and Agricultural Officer (49.00\%) were the most contacted extension personnel once in a month followed by weekly contact of Agri university scientist (48.00\%). Coming to the occasional participation NGO personnel were the most $(39.00 \%)$ rarely met extension personnel to know the information regarding farming/agriculture. The findings of the study were in line with the study conducted by Bansal and Joshi (2018) revealed that nearly half of the farm women (44-57\%) occasionally contacted various extension officials. VLEW were contacted regularly by 29 per cent of farm women. The main objective of the extension service is to introduce farmers to improved agricultural inputs and to better methods of production. In this regard, extension contact is assumed to have positive contribution to farm level volume supply of vegetables. Farmers that have frequent contact with extension agent have better access to information and could adopt better technology that would increase their marketed supply of vegetables.

Table.1 Sample distribution of vegetable producers in selected villages $n=100$

\begin{tabular}{|c|l|c|c|c|}
\hline SI No & Name of villages & $\begin{array}{c}\text { Total Number } \\
\text { of Farmers }\end{array}$ & $\begin{array}{c}\text { Number of } \\
\text { vegetable growers }\end{array}$ & $\begin{array}{c}\text { Number of Sampled } \\
\text { households }\end{array}$ \\
\hline $\mathbf{1}$ & Pendyal & 150 & 50 & 20 \\
\hline $\mathbf{2}$ & Ramachandraguda & 60 & 30 & 20 \\
\hline $\mathbf{3}$ & Kalwakole & 150 & 45 & 20 \\
\hline $\mathbf{4}$ & Dubbacherla & 100 & 35 & 20 \\
\hline $\mathbf{5}$ & Lillipur & 50 & 15 & 20 \\
\hline Total & $\mathbf{5}$ & $\mathbf{5 1 0}$ & $\mathbf{1 7 5}$ & $\mathbf{1 0 0}$ \\
\hline
\end{tabular}

Table.2 Extension Contact $\mathrm{n}=100$

\begin{tabular}{|c|c|c|c|c|c|c|}
\hline \multirow[t]{2}{*}{ S.No } & \multirow{2}{*}{$\begin{array}{l}\text { Type of Extension } \\
\text { Personnel/Contact }\end{array}$} & \multicolumn{5}{|c|}{ Frequency of contact } \\
\hline & & $\begin{array}{c}\text { Weekly } \\
\text { Once }\end{array}$ & $\begin{array}{l}\text { Once in } \\
\text { Fort Night }\end{array}$ & $\begin{array}{l}\text { Monthly } \\
\text { Once }\end{array}$ & Rarely & Never \\
\hline 1. & Horticulture Officer & $\begin{array}{c}5 \\
(5.00)\end{array}$ & $\begin{array}{c}14 \\
(14.00)\end{array}$ & $\begin{array}{c}71 \\
(71.00)\end{array}$ & $\begin{array}{l}5 \\
(5.00)\end{array}$ & $\begin{array}{l}5 \\
(5.00)\end{array}$ \\
\hline 2. & $\begin{array}{l}\text { Panchayat Samiti (Agri Extension } \\
\text { Officer) }\end{array}$ & $\begin{array}{c}26 \\
(26.00)\end{array}$ & $\begin{array}{c}44 \\
(44.00)\end{array}$ & $\begin{array}{c}20 \\
(20.00)\end{array}$ & $\begin{array}{l}6 \\
(6.00)\end{array}$ & $\begin{array}{l}4 \\
(4.00)\end{array}$ \\
\hline 3. & Agriculture Officer & $\begin{array}{c}8 \\
(8.00)\end{array}$ & $\begin{array}{c}33 \\
(33.00)\end{array}$ & $\begin{array}{c}49 \\
(49.00)\end{array}$ & $\begin{array}{l}4 \\
(4.00)\end{array}$ & $\begin{array}{l}6 \\
(6.00)\end{array}$ \\
\hline 4. & Agriculture University Scientist & $\begin{array}{c}25 \\
(25.00)\end{array}$ & $\begin{array}{c}48 \\
(48.00)\end{array}$ & $\begin{array}{c}17 \\
(17.00)\end{array}$ & $\begin{array}{l}8 \\
(8.00)\end{array}$ & $\begin{array}{l}2 \\
(2.00)\end{array}$ \\
\hline 5. & Field Assistant & $\begin{array}{c}23 \\
(23.00)\end{array}$ & $\begin{array}{c}47 \\
(47.00)\end{array}$ & $\begin{array}{c}20 \\
(20.00)\end{array}$ & $\begin{array}{l}4 \\
(4.00)\end{array}$ & $\begin{array}{l}6 \\
(6.00)\end{array}$ \\
\hline 6. & NGO Personnel & $\begin{array}{c}10 \\
(10.00)\end{array}$ & $\begin{array}{c}30 \\
(30.00)\end{array}$ & $\begin{array}{c}21 \\
(21.00)\end{array}$ & $\begin{array}{l}39 \\
(39.00)\end{array}$ & $\begin{array}{l}0 \\
(0.00)\end{array}$ \\
\hline
\end{tabular}


Int.J.Curr.Microbiol.App.Sci (2020) 9(10): 3140-3147

Table.3 Availability of market facilities $n=100$

\begin{tabular}{|l|l|l|l|l|}
\hline Sl. no & \multicolumn{1}{|c|}{ Category } & Distance from Market & \multicolumn{1}{|c|}{ F } & \multicolumn{1}{c|}{$\%$} \\
\hline \multirow{4}{*}{$\mathbf{1}$} & \multirow{2}{*}{ Distance to market } & Less than 5 Kms & 13 & 13.00 \\
\cline { 3 - 6 } & & $6-10 \mathrm{Kms}$ & 22 & 22.00 \\
\cline { 3 - 5 } & & Above $10 \mathrm{Kms}$ & 65 & 65.00 \\
\hline
\end{tabular}

Table.4 Place where produce is sold out $\mathrm{n}=100$

\begin{tabular}{|l|l|l|l|}
\hline Sr. No & Place of Sale & \multicolumn{2}{|c|}{ Response } \\
\hline $\mathbf{1}$ & Middle men & 27 & 27.00 \\
\hline $\mathbf{2}$ & Local Market & 6 & 6.00 \\
\hline $\mathbf{3}$ & Weekly Bazar & 21 & 21.00 \\
\hline $\mathbf{4}$ & Wholesale Market & 20 & 20.00 \\
\hline $\mathbf{5}$ & Retail Market & 16 & 16.00 \\
\hline $\mathbf{6}$ & Market yard & 10 & 10.00 \\
\hline & Total & 100 & 100.00 \\
\hline
\end{tabular}

Table.5 Respondents Knowledge levels towards value addition to vegetable crops n=100

\begin{tabular}{|c|c|c|c|c|}
\hline \multirow[t]{2}{*}{ S No } & \multirow[t]{2}{*}{ Statements } & \multicolumn{3}{|c|}{ Knowledge Level } \\
\hline & & High & Medium & Low \\
\hline 1 & $\begin{array}{l}\text { Do you know about the value addition of vegetable } \\
\text { produce? }\end{array}$ & $\begin{array}{c}5 \\
(5.00)\end{array}$ & $\begin{array}{c}11 \\
(11.00)\end{array}$ & $\begin{array}{c}84 \\
(84.00)\end{array}$ \\
\hline \multirow[t]{5}{*}{2} & Do you know types of value addition? & $\begin{array}{c}5 \\
(5.00)\end{array}$ & $\begin{array}{c}12 \\
(12.00)\end{array}$ & $\begin{array}{c}83 \\
(83.00)\end{array}$ \\
\hline & a. Useful form & $\begin{array}{c}4 \\
(4.00)\end{array}$ & $\begin{array}{c}8 \\
(8.00)\end{array}$ & $\begin{array}{c}88 \\
(88.00)\end{array}$ \\
\hline & b. Rightful Place & $\begin{array}{c}5 \\
(5.00)\end{array}$ & $\begin{array}{c}10 \\
(10.00)\end{array}$ & $\begin{array}{c}85 \\
(85.00)\end{array}$ \\
\hline & c. Right Time & $\begin{array}{c}6 \\
(6.00)\end{array}$ & $\begin{array}{c}11 \\
(11.00)\end{array}$ & $\begin{array}{c}83 \\
(83.00)\end{array}$ \\
\hline & d. Utility & $\begin{array}{c}5 \\
(5.00)\end{array}$ & $\begin{array}{c}12 \\
(12.00)\end{array}$ & $\begin{array}{c}83 \\
(83.00)\end{array}$ \\
\hline \multirow[t]{4}{*}{3} & Do you know three ways of value addition? & $\begin{array}{c}3 \\
(3.00)\end{array}$ & $\begin{array}{c}7 \\
(7.00)\end{array}$ & $\begin{array}{c}89 \\
(89.00)\end{array}$ \\
\hline & $\begin{array}{l}\text { a. Primary level includes cleaning, grading, } \\
\text { packing of vegetable produce? }\end{array}$ & $\begin{array}{c}6 \\
(6.00)\end{array}$ & $\begin{array}{c}12 \\
(12.00)\end{array}$ & $\begin{array}{c}82 \\
(82.00)\end{array}$ \\
\hline & $\begin{array}{l}\text { b. Secondary level includes basic processing, } \\
\text { packaging and branding. }\end{array}$ & $\begin{array}{c}2 \\
(2.00)\end{array}$ & $\begin{array}{c}2 \\
(2.00)\end{array}$ & $\begin{array}{c}96 \\
(96.00)\end{array}$ \\
\hline & $\begin{array}{l}\text { c. Tertiary level includes high end processing } \\
\text { which requires supply chain management, } \\
\text { processing technology, packaging, branding, } \\
\text { marketing etc. }\end{array}$ & $\begin{array}{c}0 \\
(0.00)\end{array}$ & $\begin{array}{c}0 \\
(0.00)\end{array}$ & $\begin{array}{c}100 \\
(100.00)\end{array}$ \\
\hline 4 & $\begin{array}{l}\text { Do you know the value added product price is higher } \\
\text { than the fresh produce? }\end{array}$ & $\begin{array}{c}6 \\
(6.00)\end{array}$ & $\begin{array}{c}27 \\
(27.00)\end{array}$ & $\begin{array}{c}67 \\
(67.00)\end{array}$ \\
\hline
\end{tabular}



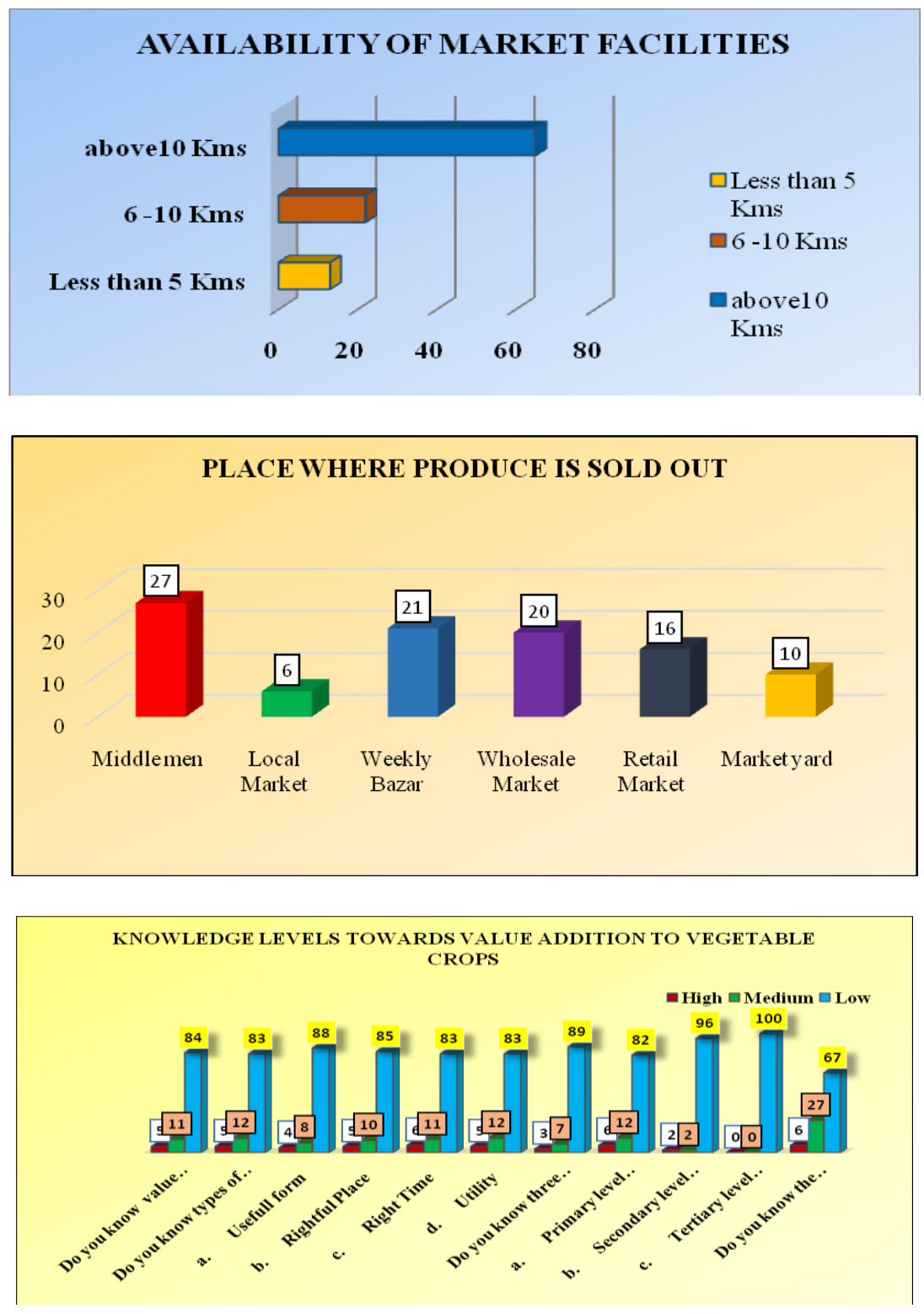

Table 3 indicates the availability of market facilities to the farmers to sell their produce at nearby places. Greatest percent 65 of respondents testified to have placed at distance of above $10 \mathrm{Kms}$ while only 13 percent of respondents reported to be situated at less than $5 \mathrm{~km}$. Contrary to priori expectations, distance to the nearest market influences positively and negatively the likelihood of choosing retailer outlet and rural collector outlet. Farmers whose residence are far from nearest market are more likely to sell their produce to retailer outlet and less likely to sell to collector outlet. Table 4 indicates the place where the farmers sell their produce at different places or persons. Most of 27 percent of respondents reported to sell to middle men followed by weekly bazar (20\%). They do realize that they get more money by selling at weekly bazaar themselves. Only 6 $\%$ of respondents stated that they sell their produce at local market viewing less storage facilities of vegetables at village level. Selling at market yards are reported by only a small $10 \%$ percent of respondents reported that the price of the vegetable at market yards depends 
on the availability and supply. Price of vegetables is uncertain and in case of fresh vegetables, there is chance of wastage.

Table 5 reveals that majority of the respondents 84 per cent possessed low level while only 11 per cent medium level of knowledge about value addition of vegetable produce. In case of cleaning, grading, packing $\&$ packaging, only 6 per cent of respondents had high, 12 per cent had medium level of knowledge, and majority 82 percent of respondents found to have low level of knowledge of it. Supreme 67 percent of respondents were found to have low knowledge that value added product price is higher than the fresh produce. The results are in harmony with Venu Prasad.et.al (2018) that sorting and grading of the produce among 62 per cent of the farmers had no knowledge and done under supervision of Safal executives the whole sale traders.

Secondary level including basic processing, packaging and branding was witnessed that 96 per cent of the respondents had low level of knowledge. As regard with Tertiary level includes high end processing which requires supply chain management, processing technology, packaging, branding, marketing etc, it was observed that 100 per cent of the respondents had low level of knowledge. The results show the requirement of trainings and awareness campaigns of vegetable growers on value addition to their produce in order to avoid post-harvest loses.

In conclusion, the outcomes of this study indicates that among total 510 number of farmers from the adopted villages only 175 are growing vegetables indicating the low availability of water and irrigation sources in the Mandal. About 32\% of the respondents reported that they had weekly access to extension service. Only $4 \%$ of the repondents reported to have access only once or twice in a year. Greatest percent 65 of respondents testified that they are placed at distance of above $10 \mathrm{Kms}$ while only 13 percent of respondents reported to be situated at less than $5 \mathrm{~km}$ to the marktes. Most of 27 percent of respondents reported to sell to middle men followed by weekly bazar (20\%) recognizing that they get more money by selling to consumers personally at weekly bazaar themselves. In regard to level of knowledge about value addition of vegetables, majority of the farm women 84 per cent possessed low level while only 11 per cent medium level of knowledge about value addition of vegetable produce. In case of cleaning, grading, packing $\&$ packaging, only 6 per cent of respondents had high, 12 per cent had medium and majority 82 percent of respondents found to have low level of knowledge.

\section{References}

Prem Singh Arya, Vegetable growing in Andhra Pradesh,", Kalyani Publishers, New Delhi, 2002, p.7. 13

Krishnaiah, "Horticulture in Andhra Pradesh; Production and Export Potentials", Indian Journal of Agricultural Economics", Vol. 52, p.625.

Agro Economic Research Institution, Fruits and vegetables mandies located in Urban and Semiurban areas of Delhi", Agricultual Situation in India, Vol.XI, p.159.

Sirohi. P.S. and Moushumi Sarkar, "Preharvest Management of Vegetables: A key of Success", Indian Horticulture, Vol.46, p-31

ManojKumar," Resource use efficiency in production of selected vegetables in Jabalpur town", Indian Journal of Agricultural Economics, Vol.48, p-48.

Anjani Kumar.et.al, (2011) Value Chains of Agricultural Commodities and their Role in Food Security and Poverty Alleviation - A Synthesis. Agricultural 
Economics Research Review Vol. 24 January-June 2011 pp 169-181.

Rani, S. and Shehrawat, P.S., Farmer's Knowledge Level Towards Value Addition in Horticulture and Vegetable Crops, Int. J. Pure App. Biosci. 6(3): 202-207 (2018).

VENU PRASAD et.al,2018, STUDY ON FARMERS

LEVEL

KNOWLEDGE
VEGETABLE CULTIVATION, Journal of Research. ANGRAU 46(2) 75-82.

Rani, S. and Shehrawat, P.S., Farmer's Knowledge Level Towards Value Addition in Horticulture and Vegetable Crops, Int. J. Pure App. Biosci. 6(3): 202-207.

\section{How to cite this article:}

Neela Rani, R., B. Jamuna Rani, Y. Uma Jyothi, T. Kamalaja, K. Swetha, J. Deepika and Rajeswari, K. 2020. Knowledge Levels of Farm Women on Value Addition of Vegetable in Ranga Reddy District. Int.J.Curr.Microbiol.App.Sci. 9(10): 3140-3147.

doi: https://doi.org/10.20546/ijcmas.2020.910.377 